\title{
EXPLOATAREA RESURSELOR ACVATICE LA COMUNITǍȚILE PREISTORICE DIN TELL-UL DE LA HÂRŞOVA (MILENIUL V BC)
}

VALENTIN RADU

\section{REZUMAT:}

În acest studiu prezentăm principalele rezultate obținute din analiza resturilor faunistice provenite din nivelurile culturale Boian și Gumelnița din tell-ul de la Hârşova cu precădere cele legate de exploatarea resurselor acvatice (moluște și pești).

Datele furnizate de resturile faunistice au contribuit la realizarea de analize complexe, comparații între nivelurile de locuire iar în ceea ce privește mediul la surprinderea unor schimbări majore în timpul locuirilor succesive cum este cazul aşezării pluristratificate de tip tell de la Hârșova.

Culesul moluștelor în scopuri alimentare era bazat pe bivalvele de apă dulce Unio și Anodonta. Pescuitul este evidențiat prin prezența a cel puțin 21 specii de pești, majoritatea de apă dulce. Importanța alimentară a peștelui crește în perioada Gumelnița odată cu exploatarea intensivă a tuturor resurselor de origine animală din mediului înconjurător.

În ceea ce privește mediul, se observă o schimbare în lista principalelor specii pescuite (creștere a ciprinidelor și a știucii în Gumelnița) și o reducere a frecvenței bivalvei Unio crassus (specie reofilă) ca urmare a modificărilor hidro-geomorfologice.

\section{ABSTRACT: EXPLOITATION OF AQUATIC RESOURCES BY THE PREHISTORIC COMMUNITIES FROM HÂRŞOVA TELL $\left(5^{\text {TH }}\right.$ MILLENNIUM BC)}

In this study we present the main results of the faunal remains from the Boian and Gumelnița cultural levels at Hârșova tell, especially those related to the exploitation of aquatic resources (molluscs and fish). The data provided by the faunal remains contributed to complex studies, the comparisons between the occupation levels and in what the environment is concerned, the observance of major changes during the successive occupations such as the case of Hârșova tell, a multi-layered settlements. The harvesting of molluscs for food was based on the freshwater bivalves Unio and Anodonta. Fishing is highlighted by the presence of at least 21 species, most of them freshwater fish.

The importance of fish in alimentation increases during the Gumelnița period together with the intensive exploitation of all animal food resources from the environment.

Regarding the environment, we noticed a change in the list of the main species of fish (increase of the cyprinids and pike during the Gumelnița) and a decreasing of the Unio crassus bivalve frequency (reophilic species) as a result of hydro and geomorphological changes.

CUVINTE CHEIE: Hârşova, cultura Boian, cultura Gumelniţa, bivalve, pești.

KEYWORDS: Hârşova, Boian culture, Gumelnița culture, bivalve, fish. 


\section{Introducere}

Resturile faunistice prelevate din așezarea pluristratificată de tip tell de la Hârşova reprezintă în cele mai multe din cazuri deșeuri menajere dar se constituie într-o sursă importantă de informații pentru descifrarea vieții cotidiene a locuitorilor care au trăit în această sit de-a lungul mileniului al cincilea $\mathrm{BC}^{1}$. În cele ce urmează vom încerca să rezumăm principalele rezultate obținute în urma studiului a acelor resturilor ce provin din exploatarea resurselor acvatice (cu precădere a celor de moluște și pești) de către comunitățile Boian și Gumelniţa.

Tell-ul de la Hârșova a fost descoperit în anul 1960 și cercetat arheologic de Doina Galbenu în anii 1961-1963, 1971 și $1975^{2}$. După o perioadă de pauză în anul 1985 cercetările au fost reluate sub conducerea lui Dragomir N. Popovici și a lui Puiu Haşotti³. Începând din 1993 se adaugă şi o echipă de cercetători francezi condusă de Bernard Randoin în cadrul unui program de cooperare arheologică româno-francez ${ }^{4}$.

Arheologii au identificat mai multe niveluri culturale ce au fost atribute culturilor Boian-Vidra, Boian-Spanţov şi Hamangia III, Gumelniţa A1, Gumelniţa A2 și Cernavodă I ${ }^{5}$. Suprafaţa cercetată iniţial de către D. Galbenu a fost sondajul A (SA) ce s-a extins mai apoi cu suprafețele B (SB) și C (SC). Totalul suprafeței cercetate a fost estimat de către P. Haşotti ${ }^{6}$ la aproximativ $400 \mathrm{~m}^{2}$ din care $80 \mathrm{~m}^{2}$ doar în $\mathrm{SC}^{7}$. Ultima suprafață $\mathrm{SC} / \mathrm{pP}$ este cercetată începând cu anul 2010 şi după extinderi succesive ajunge la circa $100 \mathrm{~m}^{28}$.

Din 1993 cercetarea arheologică se realizează după o metoda stratigrafică ce se bazează pe înregistrarea tuturor caracteristicilor identificate în unitățile stratigrafice ${ }^{9}$. Acestea reprezintă acumulări ale unor depuneri arheologice ce caracterizează un anumit moment sau o activitate din formarea și evoluția sitului. Informațiile obținute astfel permit documentarea istoricului detaliat al acumulărilor atât pe orizontală cât și pe verticală a nivelelor de locuire așa cum se reflectă în rețeaua de relații spațiale și temporale dintre unitățile stratigrafice individuale.

Rezultatele cercetărilor arheologice pentru perioadele culturale Boian și Gumelnița sunt numeroase mai ales că începând din anul 1993 ele au și un caracter multidisciplinar. Astfel analizele de sedimentologie au avut rolul de

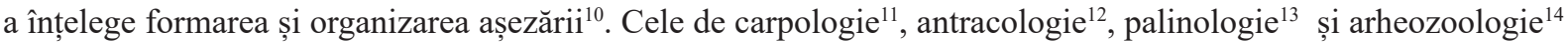
au încercat să surprindă rolul plantelor și animalelor în alimentaţia locuitorilor dar și în paleoeconomia animalieră şi indirect au contribuit la reconstituirea mediului în perioada locuirilor preistorice cât și la sezonalitatea acestor activităţi și a indicatorilor lor specifici ${ }^{15}$.

Până în prezent aceste studii au evidențiat existența unei organizări spațiale riguroase și prezența unor modele evidente de organizare spațială în această așezare. Astfel locuințele erau dispuse în rânduri separate prin spații de trecere cu lățimea variabilắn

Locuințele noi au fost construite în mare parte pe același amplasament al locuințelor abandonate mai vechi (care puteau fi arse sau nu). Planurile arhitecturale coerente ale acestei așezări, activităţile de construcție continuate şi repetate, precum şi rezultatele studiilor structurilor arheologice individuale demonstrează împreună că aşezarea a funcționat pe tot parcursul anului ${ }^{17}$.

Durata locuirilor din perioadele Boian și Gumelnița a fost stabilită pe baza datărilor radiocarbon și se eșalonează între cca 4700 și $4000 \mathrm{cal} \mathrm{BC}^{18}$.

Popovici 2010; Ștefan 2010.

Galbenu 1962; Galbenu 1963; Galbenu 1966; Galbenu 1979.

Popovici et al. 1992; Popovici, Randoin, Rialland 2001.

4 Vezi rapoartele de cercetare arheologică de la Hârșova tell publicate în Cronica Cercetărilor Arheologice din România din anii 1994-2007, 2010-2012, 2014, 2016 și 2017 (Cronica 1983-2017) și Popovici, Randoin, Rialland 2001; Popovici et al. 2012a.

5 Haşotti 1989; Haşotti, Popovici, 1992; Popovici, Haşotti 1992; Haşotti 1997.

6 Haşotti 1997, 79.

Haşotti 1997, 68.

8 Popovici et al. 2016.

9 Randoin, Popovici, Rialland 2000; Popovici, Randoin, Rialland 2001; Popovici et al. 2002.

10 Haită 2000; Haită 2001; Haită 2012a.

11 Monah 2000.

12 Tomescu 2004.

13 Tomescu 2000a.

14 Sárkány-Kiss, Boloș 1996; Moise 2000; Gál, Kessler 2002; Bălășescu, Moise, Radu 2005; Bălășescu, Radu, Moise 2005; Bălăşescu, Moise, Radu 2006; Mărgărit, Popovici 2011; Bréhard, Bălășescu 2012; Mărgărit, Popovici 2012a; Mărgărit, Popovici 2012b.

15 Radu 2000; Tomescu 2000b; Haită, Radu 2003; Tomescu, Radu, Moise 2003; Le Bailly et al. 2006; Bréhard et al. 2014.

16 Popovici, Randoin, Rialland 2001; Popovici 2010.

17 Popovici et al. 2000; Popovici, Randoin, Rialland 2001; Haită, Radu, 2003; Tomescu, Radu, Moise 2003; Bréhard, Bălăşescu 2012; Popovici et al. 2012b; Bréhard et al. 2014; Popovici et al. 2014; Popovici et al. 2016.

18 Popovici, Randoin, Rialland 2001; Bréhard, Bălăşescu 2012; Mărgărit, Radu, Popovici 2016. 
Dintre structurile arheologice descrise și studiate în această aşezare cele mai bogate în resturi faunistice s-au dovedit a fi zonele de deșeuri menajere. Acestea au fost definite și studiate interdisciplinar pentru prima dată în tell-urile culturii Gumelnița din valea Dunării de la Hârșova și Bordușani. Categorie a spaţiului locuit caracteristică pentru tell-urile eneolitice, zonele de deșeuri menajere s-au dovedit a fi surse importante de informaţii privind reconstituirea vieții comunităților umane ${ }^{19}$. Asemenea structuri sunt frecvent întâlnite „de façons généralisées” în cele două tell-uri² ${ }^{20}$.

În cele mai multe cazuri sunt formate în aria în care a funcţionat o locuință incendiată sau neincendiată, parțial distrusă și abandonată. În acest spațiu se acumulează diverse deșeuri: cenușă și cărbuni, oase provenind de la diverse animale, solzi de pește, cochilii de moluște, fragmente ceramice, bucăți de chirpici sau materiale rezultate de la construcția sau refacerea locuințelor, unelte de silex sau piatră etc. ${ }^{21}$. Cantitățile acumulate variază în funcție de activitățile generatoare de deșeuri, de sezon, dar și de durata de utilizare a acestor zone ${ }^{22}$. Prelevarea atentă a unităţilor acumulate şi cernerea sedimentului a permis recuperarea diverselor materiale existente, chiar şi a celor de mici dimensiuni, într-o ordine temporală inversă a depuneri lor. Astfel zonele de deșeuri se pot defini ca o componentă caracteristică a evoluției crono-stratigrafice a sitului²3.

Studiul materialelor arheofaunistice a fost realizat nu numai pentru obținerea unor date privind activităţi precum culesul moluștelor, pescuitul, creșterea animalelor sau vânătoarea ci și pentru evidențierea proceselor şi activităților care le-au generat și sezonalitate. Cercetarea lor poate oferi date importante privind modelul de gestiune a diferitelor resurse alimentare și strategiile specifice adoptate.

\section{Material și metode}

Materialele faunistice prelevate din nivelurile eneolitice de la Hârșova suprafețele SC și SB au fost studiate începând cu 1993 și publicate în lucrări de sinteză privind comunităţile eneolitice din Romania ${ }^{24}$. Pentru nivelul Boian (Fig. 1) s-au selectat materialele din suprafața SC prelevate în anul $1994^{25}$ iar din suprafața SC/pP cele din anii $2016^{26}$ şi $2017^{27}$, singurele cu o încadrare culturală clară.

Pentru nivelul Gumelnița (Fig. 1) au fost reținute datele din suprafaţa SB publicate în anii 1994-200028 și inedite din 2006 (Radu inedit) iar din suprafața SC/pP datele din 2011 care conform responsabililor de șantier ${ }^{29}$ ar putea fi atribuite unui nivel de tranziție între Gumelnița și Boian.

În total au fost luate în considerare pentru acest studiu 361651 resturi faunistice. Dintre acestea 7113 resturi de pește și 2120 resturi de moluște reprezintă 70,3\% din totalul resturilor analizate pentru nivelul Boian iar pentru cel Gumelnița 285461 resturi de pește și respectiv 55555 de moluște (97,8\%). Numărul mare de resturi se datorează faptului că mare parte din structurile arheologice analizate sunt eșantionate și prelevate sistematic iar apoi sedimentul este cernut prin site (1,2 sau $4 \mathrm{~mm})$. 10542,5 litri de sediment au fost cernuți pentru nivelul Gumelniţa $^{30}$ și doar 206 litri pentru cel Boian. În felul acesta s-au obținut resturile fragile aparţinând scheletului peștilor care sunt de ordinul miilor, acestea atingând și frecvențele cele mai mari în cuantificarea faunei (54\% în Boian și respectiv 82\% în Gumelnița). Avantajele aplicării acestei metode de prelevare sunt multiple ${ }^{31}$ iar pentru structurile studiate ne-au permis diverse abordări de natură cantitativă și calitativă. Uneori interrelaţionarea acestor informații cu cele provenite de la acumulările specifice rezultate ale activităţilor umane (chirpici, cenușă, ceramică etc.) a condus la realizarea unor scheme microcronostratigrafice. Faptul că de-a lungul unui mileniu s-au acumulat peste $12 \mathrm{~m}$ de sedimente a constituit pentru obiectele și structurile de locuire rămase după locuirea neo-eneolitică un mediu izolator ce a permis foarte puțin factorilor tafonomici să intervină asupra lor. De asemenea gradul de intruziune al elementelor post locuire este minim (galerii de animale, intervenții din perioadele culturale posterioare etc.) ceea ce a contribuit în mică măsură la afectarea rezultatelor, cel puțin în cazul studiilor de arheozoologie.

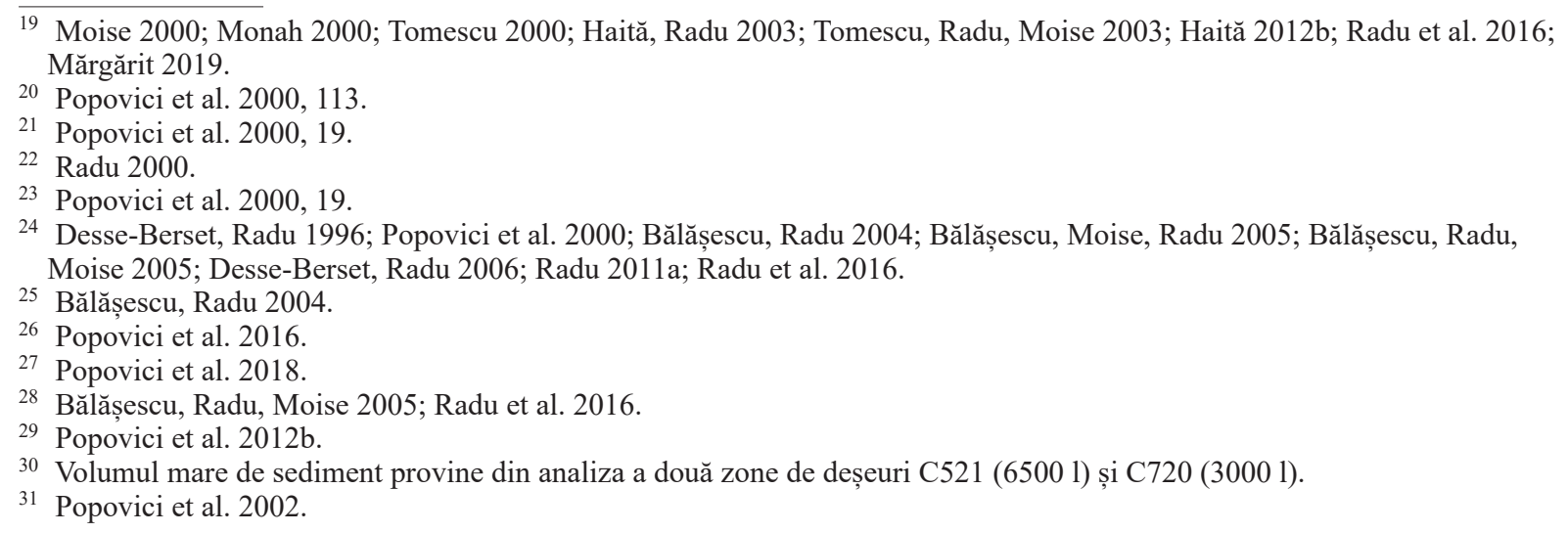


Caracterizarea diferitelor clase de animale s-a realizat prin metodele clasice ale arheozoologiei, determinare, cuantificare, date biometrice ${ }^{32}$, morfometrie ${ }^{33}$ dar s-a folosit și metoda izotopilor stabili ${ }^{34}$ sau studii de genetică ${ }^{35}$.

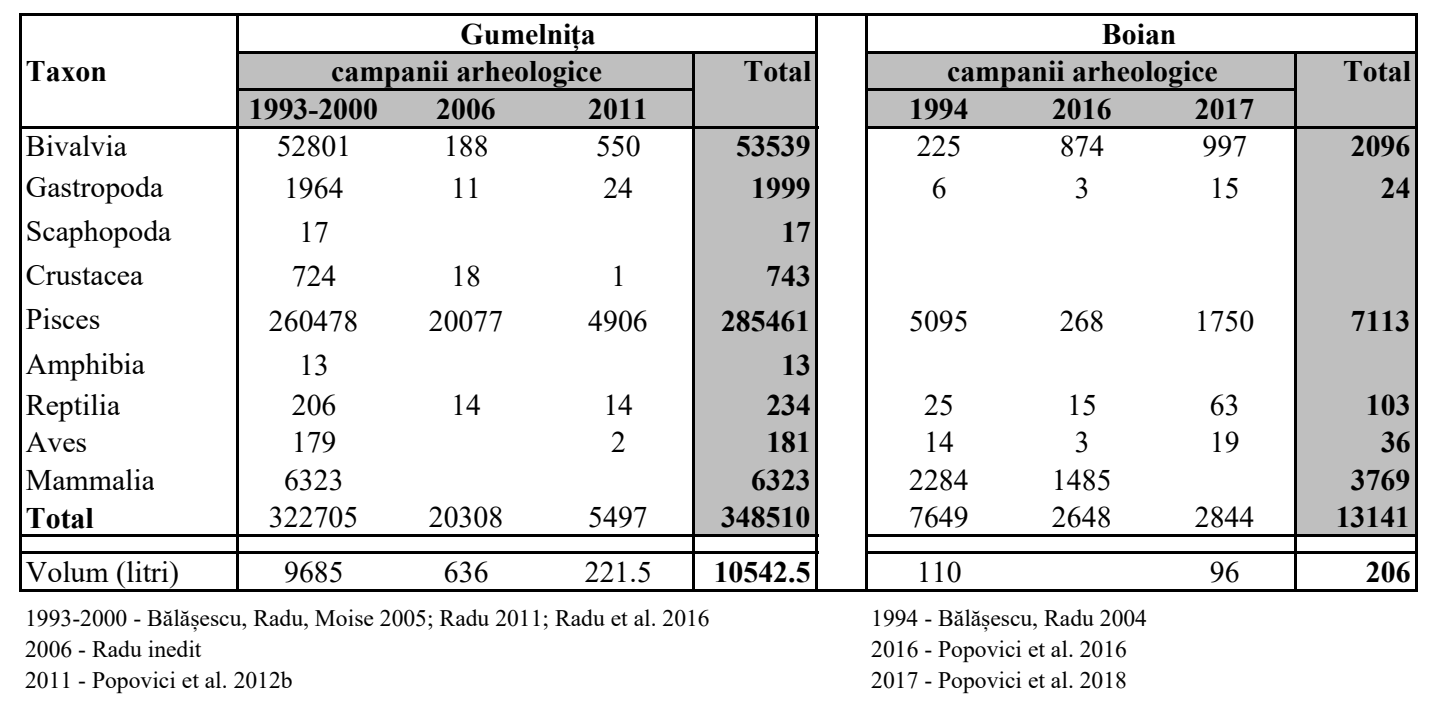

Figura 1. Resturile faunistice de la Hârșova tell analizate în acest studiu (nivelurile Boian și Gumelnița).

\section{Rezultate}

Paleoeconomia animalieră a comunităților Boian si Gumelnița de la Hârșova a fost deja conturată prin câteva lucrări de sinteză $\breve{a}^{36}$. Astfel se observă că creșterea animalelor joacă un rol foarte important în cadrul vieții comunităților de la Hârşova tell dar aceasta diminuează de la $90 \%$ în perioada Boian spre $60 \%$ (după numărul de resturi) în perioada Gumelnița. De asemenea ponderea bovinelor scade în Gumelnița, în timp ce procentajele ovicaprinelor şi porcinelor cresc. În toate perioadele culturale se remarcă fenomenul cynofagiei. Vânătoarea nu are o importanţă foarte mare în nivelurile Boian Spanțov dar ponderea ei crește în nivelurile Gumelnița până la 24\% (după numărul de resturi). Speciile cele mai vânate sunt mistrețul și cerbul.

Resursele acvatice și modalitățile lor de exploatare (mai ales culesul moluștelor și pescuitul) sunt bine evidențiate prin diverse studii la Hârşova tell $^{37}$ față de alte așezări contemporane cercetate ${ }^{38}$. Culesul moluștelor și pescuitul sunt activităţi care furnizează cantități importante de proteină animală necesare în alimentaţia locuitorilor. Mai mult, studii recente realizate atât la Hârșova tell dar și la Bordușani Popină (cultura Gumelnița) au arătat că există o strategie clară de exploatare a resurselor animale. În perioada rece erau sacrificate mai multe ovicaprine decât în perioada estivală când necesarul de proteină animală era compensat în special de către pești și bivalve ${ }^{39}$.

Moluște. Dintre toți taxonii identificați speciile acvatice sunt cel mai bine reprezentate în eșantioanele studiate $(99,99 \%)$. Singurele specii terestre aparțin gasteropodelor (Tab. 1). Acestea de cele mai multe ori sunt aduse de om involuntar și nu cu scopul de a fi consumate sau trăiesc în zonele locuite ${ }^{40}$. O mare parte din gasteropodele acvatice sunt aduse tot involuntar. Dintre acestea singurele susceptibile de a fi consumate sunt cele din genul Viviparus.

Dintre bivalve, genurile Unio și Anodonta sunt dominante cu frecvențe generale de 80-90\% din totalul bivalvelor. Speciile marine precum Cardium sunt sporadice și ele provin din schimburi pentru confecționarea de podoabe ${ }^{41}$. Acumulările de cochilii din genurile Unio și Anodonta din zonele de deșeuri menajere au constituit un bun prilej

\footnotetext{
32 Popovici et al. 2002.

33 Evin et al. 2015.

34 Balasse et al. 2016; Balasse et al. 2017.

35 Larson et al. 2007; Ollivier et al. 2016.

36 Bălășescu, Radu 2004; Bălășescu, Radu, Moise 2005; Bălășescu, Moise, Radu 2005; Radu 2011a.

37 Desse-Berset, Radu 1996; Radu 2000; Desse-Berset, Radu 2006; Radu 2011a; Radu et al. 2016.

38 Mai există astfel de studii la Pietrele (Beneke et al. 2013; Ritchie 2017), Bordușani (Radu 1997; Radu 2003a; Radu et al. 2016), Vitănești (Radu 2011b), Luncavița (Radu 2003b) și Năvodari (Radu 2001).

39 Tomescu, Radu, Moise 2003; Brehard et al. 2014; Radu et al. 2016.

40 Radu 2011a, 76.

41 Mărgărit, Popovici 2012a; Mărgărit 2019.
} 
de a cuantifica rolul în alimentație al bivalvelor și nu numai ${ }^{42}$. Pe lângă rezultatele legate de cantitățile culese, frecvența culesului, locul de colectare și importanța în alimentația locuitorilor preistorici acestea mai pot oferii informații legate de mediul înconjurător sau de evoluția acestuia (schimbări ale cursului râului sau modificări ale dinamicii acestuia), fluctuațiile estivale importante ale nivelului râurilor (după componența specifică, dimensiuni), anumite strategii de construcție și de organizare a spațiului adoptate și modul lor de corelare cu evoluția mediului, sezonalitate și evoluție a climei la o scară de timp contemporană cu locuirea umană prin studierea acumulărilor izotopului stabil de oxigen ${ }^{43}$.

În acest sens au fost supuse studiului eșantioane ce au provenit atât din nivelul Gumelnița, zona de deșeuri C521 cât și din nivelul Boian, suprafața $\mathrm{SC} / \mathrm{pP}^{44}$.

Se observă că cele mai frecvente bivalve sunt cele trei specii de Unio (U. tumidus, U. pictorum şi U. crassus) şi cele din genul Anodonta (Anodonta sp.). Pe baza acestor materiale s-a urmărit raportul dintre Unio și Anodonta, specii cu necesități ecologice diferite, care a fost comparat cu valori ale celui obținut în zilele noastre pe eșantioane din diferite puncte reprezentative pentru lunca Dunăriii ${ }^{45}$. S-a observat astfel că datele arheologice corespund cel mai bine cu cele obținute pentru șenalul fluviului sau pentru un braț permanent al său. Astfel s-a concluzionat că locuitorii din așezarea de la Hărșova tell, fie ei din perioada Boian sau Gumelniţa recoltau bivalvele din locuri aflate pe malul fluviului în imediata apropiere a aşezării. Analiza dimensiunilor acestor bivalve în comparație cu cele actuale ne arată în plus că aceste locuri erau foarte frecventate iar prelevările multiple au condus la reducerea dimensiunilor bivalvelor afectând populațiile din imediata vecinătate a tell-ului ${ }^{46}$. Acest fenomen (supracules/cules intensiv) nu s-ar fi întâmplat dacă nu exista un interes pentru consumul acestor bivalve, un loc de cules accesibil apropiat de sit dar și un nivel al fluviului ce permitea concentrarea bivalvelor și accesul facil la această sursă de hrană.

În nivelurile de locuire s-a observat prezența fragmentelor de cochilii aproape în toate structurile arheologice. Identificarea și cuantificarea acestora a permis observarea de fluctuaţii cantitative ce variază de la câteva valve la câteva zeci de mii ce cântăresc sute de kg. Pe de o parte aceasta reflectă un consum variabil ce poate fi legat de gradul de accesibilitate la sursele din mediu (ce diferă în perioadele de secetă, de inundații etc.) dar și de modalitățile de consum ce puteau fi zilnice sau ocazionale, individuale sau familiale. Depunerile de ordinul sutelor de kg de valve întâlnite în nivelul Gumelnița (C521) de la Hârşova tell (peste $500 \mathrm{~kg}$ ) nu sunt singulare și au fost identificate și la Bordușani Popină. Ele au caracterul unor festinuri care au fost acompaniate de un consum de carne de pește pe măsură şi mai puțin din cel de mamifere ${ }^{47}$. Două ipoteze au fost propuse în cazul acestor acumulări: sărbătorirea unor evenimente sezoniere legate de accesibilitatea la mari cantități de bivalve sau construcția unei noi locuințe în acest caz bivalvele intrând în compoziția patului de amenajare cu rolul de a drena umiditatea de la nivelul podelelor ${ }^{48}$.

$\mathrm{Cu}$ aceste ocazii s-au realizat aproximări ale valorii energetice furnizate atât de bivalve ${ }^{49}$ cât și de pești ${ }^{50}$ precum și ale numărului de persoane care ar fi putut fi hrănit cu aceste cantități. Chiar daca aceste valori sunt ipotetice ele au abordat dintr-o altă perspectivă problema demografică a acestei aşezări care se baza doar pe numărul complexelor de locuire descoperite.

Un alt studiu realizat în suprafața SB a fost legat de suprafața din faţa intrării în locuinței SL68. S-au eșantionat şi cernut 636 litrii de sediment prelevat din depunerile aflate în zona de trafic din intrarea în locuința SL68 dar şi dintr-o suprafaţă aflată în apropierea unui gard a acesteia. În acest caz, cum era normal, depunerile cele mai consistente erau în apropierea gardului, suprafața fiind mai puțin circulată și deranjată. Din punctul de vedere al moluștelor s-a observat că acestea sunt în număr redus în aceste suprafețe de trafic intens (sub 1\%) față de zonele în care se depun doar deșeuri.

O altă situație întâlnim în suprafața centrală (complexul C720), analizată începând cu campania 200051, care pare a fi o zonă comună, de acces între mai multe locuințe. Comparativ cu zona de deșeuri C521 procentul resturilor de moluște este la jumătate $(8,4 \%)$ iar speciile dominante sunt bivalvele Anodonta sp. și gasteropodul Viviparus sp. Aici zonele de trafic alternează cu perioade când este folosită ca zonă de deșeuri dar față de curtea SL68 evoluează pe o perioadă de timp mai îndelungată. Gasteropodul Viviparus sp. pare a fí utilizat pentru stabilizarea solului fiind

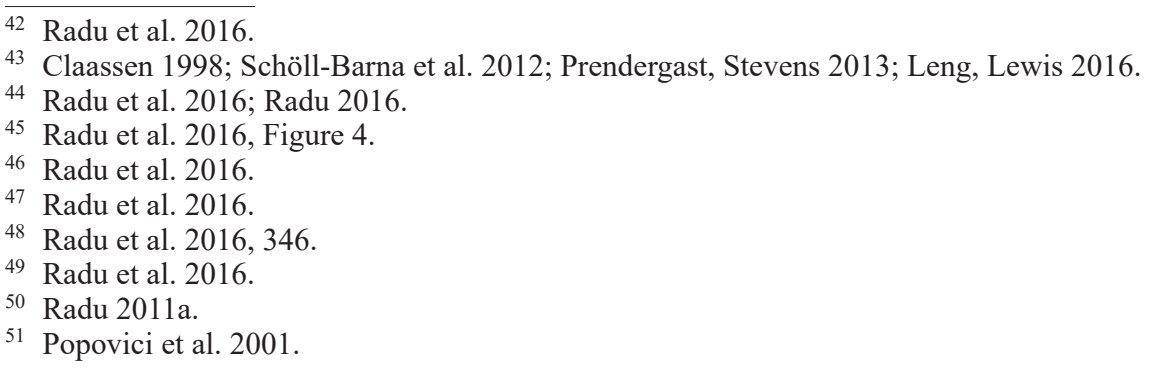


dispus în straturi succesive ce alcătuiau un fel de pavaj. Analiza gasteropodelor a condus la stabilirea faptului că acestea conțineau cochiliile juvenililor iar în momentul depunerilor în aceste straturi indivizii de Viviparus sp. au fost intenționat colectați cel mai probabil din tanatocenoza de pe malurile Dunării.

Aceste rezultate demonstrează că pe lângă rolul lor alimentar moluștele, alături de alte materiale de natură organică au varii utilizări și în cadrul organizării și amenajării spațiului.

Pești. Resturile aparținând peștilor sunt în cea mai mare parte a lor de mici dimensiuni și fragile ceea ce face ca prelevarea lor să fie minuțioasă și să necesite obligatoriu pentru un studiu pertinent cernerea unui anumit volum de sediment $^{52}$. La Hârșova tell mare parte din eșantioanele studiate au fost astfel obținute permițându-ne comparații între diferitele structuri cercetate și chiar studii de sezonalitate.

S-au identificat 21 de specii de pești (Tab. 2) majoritatea provenind din Dunăre sau râurile tributare: migratoare anadrome (trăiesc în Marea Neagră dar urcă pe Dunăre sau afluenți pentru a se reproduce) precum sturionii, păstruga (Acipenser stellatus), morunul (Huso huso) sau scrumbia de Dunăre (Alosa pontica); migratoare catadrome (urcă pe Dunăre pentru a se hrăni) Anquilla anquilla (anghila); specii de apă dulce comune în Dunăre și afluenții săi: acipenseride - Acipenser ruthenus (cegă); esocide - Esox lucius (ştiucă); cyprinide - Abramis brama (plătică), Alburnus alburnus (oblet), Aspius aspius (avat), Blicca bjoerkna (batcă), Carassius carassius (caracudă), Cyprinus carpio (crap), Leuciscus idus (văduviţă), Pelecus cultratus (sabiţă), Rutilus rutilus (babuşcă), Scardinus erythrophthalmus (roşioară), Tinca tinca (lin); siluride - Silurus glanis (somn) sau percide - Gymnocephalus (Acerina) sp. (ghiborţ), Perca fluviatilis (biban), Stizostedion lucioperca (şalău).

Aceste specii au fost identificate în ambele culturi mai puțin caracuda (Carassius carassius) și văduvița (Leuciscus idus) în nivelul Boian. Lipsa celor doi taxoni poate fi consecința a unui numărul redus de eșantioane studiate sau a utilizării unor unelte de pescuit diferite și de ce nu chiar a unor cauze ecologice. Anghila este de asemenea o apariție rară ce este documentată cu un rest (o vertebră) în nivelul Gumelnița.

Ciprinidele prezintă frecvențele cele mai mari în ambele culturi după numărul de resturi $(64,2 \%$ Boian, respectiv 75,4\% Gumelnița). Ca specii se observă însă că pentru perioada Boian, mai ales în nivelurile din SC/pP somnul, sturionii și crapul sunt cele mai pescuite. Indivizii acestor specii pot ajunge la cele mai mari dimensiuni întâlnite pentru peștii din apele dulci. Pentru perioada Gumelniţa şalăul, știuca și apoi crapul și somnul ocupă întâietate pe lista speciilor pescuite (Tab. 2). Alte două specii de ciprinide capătă importanță precum plătica și babușca ce apar cu resturi aproape în toate eșantioanele analizate. Se observă o lărgire a spectrului specific cu specii ce sunt prezente mai mult în zonele cu bălţi și lacuri.

Apar diferențe și în ceea ce privește dimensiunile peștilor din cele două culturi. În Boian dimensiunile medii de pescuit sunt în general mai mari decât în perioada Gumelnița ${ }^{53}$. Exemplificăm cu câteva rezultate obținute în cazul somnului (Silurus glanis) ce pot fi generalizate pentru aproape toate speciile importante (Fig. 2). Eșantioanele folosite pentru comparație provin din nivelurile Boian cercetate în suprafața SC/pP iar cele Gumelnița din suprafața B, complexul C521 (Tab. 2). Limitele lungimii totale (Lt) ale indivizilor prezumaţi sunt între 0,7-2,5 m (2,3-111 kg) pentru Boian (25 indivizi) și respectiv 0,2-2,3 m (0,06-80 kg) pentru Gumelniţa (95 indivizi).

Dimensiunile frecvente de pescuit calculate pentru Boian sunt între 0,9 şi 1,6 m lungime totală (5-26 kg) ceea ce reprezintă 88\% din totalul indivizilor iar pentru Gumelnița între 0,4 și 1,2 m Lt (0,5-11 kg) respectiv 70\% din total. Observăm că indivizii capturați în Boian fac parte majoritatea din grupul reproducătorilor. Și în cazul crapului este validă această observație ceea ce ne indică că unelte și metode de pescuit erau probabil asemănătoare pentru aceste două specii.

Pentru uneltele și metodele de pescuit folosite la Hârşova nu avem descoperite decât artefacte ce pot fi atribuite ca fiind legate de această activitate precum harpoanele ${ }^{54}$ și ancore de barcă ${ }^{55}$ precum și datele indirecte obținute de la speciile capturate rezultate din etologia, ecologia și dimensiunile lor. Dimensiunile mai mari ale peștilor capturați în perioada Boian se datorează atât uneltelor de pescuit dar și unui pescuit oportunist. Utilizarea cu preponderență a unor unelte de tipul priponului dar și pescuitul oportunist în perioadele când peștii sunt vulnerabili (în perioada de reproducere sau la secarea bălţilor) conduce la o selecție dimensională involuntară şi la capturi de mari dimensiuni cu mijloace simple. Cantitățile, după cum reflectă datele obținute pentru ambele perioade, nu sunt mari dar calitatea este crescută ${ }^{56}$. Pentru perioada Gumelnița observăm practic dublarea numărului de resturi provenind de la ciprinide ca de altfel și apariția unor alte specii cu frecvențe crescute printre principalele capturi precum știuca, de circa 7,2 \%, care avea valori de sub $1 \%$ în eșantioanele culturii Boian. Dacă adăugăm la aceste

\footnotetext{
52 Desse-Berset, Radu 1996; Desse-Berset, Radu 2006.

53 Radu 2011.

54 Radu 2007-2008; Mărgărit, Popovici 2012.

55 Parnic 2007-2008.

56 Desse-Berset, Radu 1997.
} 


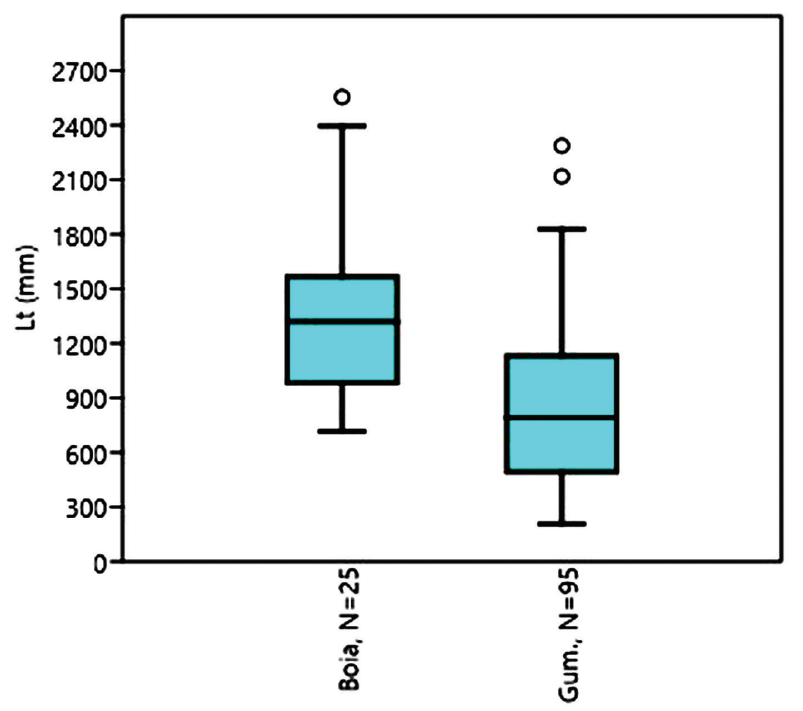

Figura 2. Lungimea totală (Lt) calculată pe baza dimensiunilor primei radii a înotătoarei pectorale de somn (Silurus glanis). Eșantionul Boian provine din zonele de deșeuri identificate în SC/pP, campaniile 2016-2017, iar cel Gumelniţa din SB, zona de deșeuri C521.

date și reducerea generală a dimensiunilor de captură observăm, deși prin dovezi indirecte, că atât uneltele cât și strategiile de pescuit s-au schimbat. Pescuitul devine o activitate intensivă de procurare a unor cantități mari de pește calitatea fiind trecută într-un plan secundar. În acest scop probabil că plasele de pescuit vor fi fost mai mult utilizate decât alte unelte de pescuit, ca de altfel și dezvoltarea şi perfecționarea unor metode de pescuit pentru acele perioade când pescuitul nu se putea realiza doar cu mijloace rudimentare (la mână sau cu harponul) sau chiar oportunist pentru exploatarea eficientă a potențialului oferit de mediul din apropierea sitului.

Studiile pentru cunoașterea sezonului de pescuit efectuate la Hârșova au fost realizate pentru două zone de deșeuri (C521 și US 1523) din nivelul Gumelnița ${ }^{57}$. Au fost utilizate vertebrele de crap și șalău speciile cele mai pescuite dar care au și vertebrele cele mai mari și care permit citirea inelelor de creștere și stabilirea cu o anumită probabilitate a sezonului de captură ${ }^{58}$. S-a urmărit atât precizarea sezonului de pescuit iar pe baza relațiilor stratigrafice informații referitoare la evoluția zonelor de deșeuri și realizarea unor scheme de microcronostratigrafie. Datele obținute cu această ocazie, susțin faptul că pescuitul se realiza cu preponderență în perioada estivală, odată cu debutul perioadei de reproducere pentru majoritatea speciilor și mai rar iarna sau la începutul primăverii. Pentru zona de deșeuri C521 s-a aproximat chiar și durata de funcționare, de circa un an și totodată s-au asociat diferitele activități identificate (amenajări, refaceri ale locuințelor, arderea combustibilului lemnos etc.) cu o anumită perioadă din timpul unui $\mathrm{an}^{59}$.

Alte animale. Contactul locuitorilor de la Hârșova tell cu mediul acvatic a permis valorificarea în alimentație și nu numai și a altor animale precum racii, amfibienii, reptilele sau păsările.

De la raci (Astacus sp.) au fost identificate gastrolite (noduli de calcar folosiți în perioada năpârlirii) și resturi arse ale apendicelor locomotori mai ales în nivelurile Gumelnița ${ }^{60}$. Tot aici sunt prezente resturi ale broaștelor de lac (Rana sp.) dar și ale țestoasei de apă (Emys orbicularis) care puteau fi surse potențiale de hrană. Țestoasa de stepă (Tesudo graeca) prezentă și ea în zona carstică din vecinătatea sitului e mai rar consumată. Păsările identificate în nivelul Gumelnița aparțin la 10 ordine, jumătate din acestea fiind migratoare ${ }^{61}$. Au fost observate urme de tranșare ce atestă consumul și s-au identificat și coji de ouă ${ }^{62}$. Totuși păsările reprezintă o sursă de hrană de mai mică importanță precum și o sursă de materii prime reprezentate prin oase și pene pentru diverse activități.

\footnotetext{
57 Radu 2000; Haită, Radu 2003; Radu 2011a.

58 Casteel 1976.

59 Popovici et al. 2000.

60 Radu 2011, 186.

61 Gál, Kessler 2002.

${ }^{62}$ Radu 2011a, 191, fig. 111.
} 


\section{Prelucrarea materiilor dure animale}

Resturile animalelor au fost utilizate și ca materie primă pentru realizarea de unelte și podoabe. Cochilia moluștelor de Cardium a fost perforată şi utilizată pentru podoabe ca și cea a scafopodului Dentalium ${ }^{63}$. Valvele de Unio au fost transformate atât în unelte cât și în discuri perforate ce intrau în compoziția podoabelor ${ }^{64}$. Astfel de discuri au fost realizate și din oasele operculare ale crapului ${ }^{65}$. Carapacea țestoasei Testudo graeca prezintă și ea modificări ce ne indică că a fost utilizată probabil pentru realizarea de recipiente ${ }^{66}$.

\section{Mediu}

Datele obținute în special de la moluște au reuşit să surprindă modificări ale mediul din jurul tell-lui dar au oferit și informații legate de peisajul din lunca Dunării. O analiză a moluștelor identificate în diversele eșantioane studiate relevă că cele mai frecvente sunt speciile acvatice ${ }^{67}$.

Dintre acestea cochiliile gasteropodelor de Viviparus împreună cu cele de Lithogliphus, Theodoxus și Esperiana sunt prezente aproape în toate eșantioanele. Mai mult, Lithogliphus și Theodoxus sunt specii reofile fiind întâlnite preponderent doar în ape curgătoare. În ceea ce privește bivalvele, dominante sunt cele trei speciile de Unio (U. tumidus, U. pictorum și U. crassus) iar analiza raportului cu Anodonta (număr de cochilii) ne-a arătat că valorile obținute sunt asemănătoare cu cele recoltate din fluviu sau dintr-un braț al acestuia ${ }^{68}$. După cum se observă mare parte din speciile de moluște acvatice sunt caracteristice pentru fluviu sau brațele sale și deci este de presupus că aşezarea era în apropierea fluviului iar bălțile și zona inundabilă erau mai puțin frecventate pentru exploatarea resursele acvatice, cel puțin pentru perioada Boian. Tot în această perioadă observăm că frecvențele valvelor de Unio crassus pot ajunge și până la 34\% din totalul moluștelor în timp ce mai târziu în Gumelniţa acestea au o medie de doar 4\%. Astfel de date au fost observate și la Bordușani Popină și deci presupunem că aceste modificări pot fi cauzate mai mult de condițiile ecologice decât cele antropice legate de preferințele alimentare. Această specie prefera substratul nisipos, o viteză mare a apei și un nivel crescut de oxigen ${ }^{69}$. Probabil că în evoluția luncii Dunării din această perioadă (a doua parte a mileniului V BC) s-au modificat parametrii regimului hidrologic general precum scăderea vitezei de curgere, reducerea zonelor cu canale și creșterea suprafețelor cu bălți și lacuri, accentuarea colmatării văii inundabile etc. și nu au mai fost compatibili cu cei ce permiteau dezvoltarea optimă a acestei specii. În plus aceste modificări au condus și la reducerea numărului de indivizi din speciile de pești reofili care reprezintă gazdă obligatorie în ciclul de dezvoltare al acestei scoici ${ }^{70}$ (în stadiul larval de dezvoltare larva glochidium e parazită pe anumite specii de pești).

Astfel, modificările hidro-geomorfologice vor contribui şi la schimbarea tehnicilor de pescuit. Zonele inundabile, bălțile și lacurile devenind preponderente în perioada Gumelnița în lunca Dunării ${ }^{71}$ se vor folosi mai mult plasele, harpoanele sau chiar barajele (precum gardurile) la retragerea apelor, coșurile oarbe sau chiar pescuitul cu mâna în ochiurile de apă rămase. Speciile reofile, cele mai frecvent pescuite în perioada Boian precum sturionii, somnul sau crapul vor fi înlocuite în cea Gumelnița de ciprinide dar și de știucă sau șalău. Știuca, a doua specie ca frecvență, o putem încadra chiar ca specie indicatoare a zonelor inundabile sau a celor cu ape nu foarte adânci (bălţi). Acest pește vorace rămâne uneori ultimul supraviețuitor în astfel de zone hrănind-se cu abundența de ciprinide juvenile existente după perioada de reproducere sau prezente în bălți în curs de secare iar la final ajunge chiar să se devoreaze între ei.

\section{Concluzii}

Resursele acvatice exploatate de comunitățile Boian și Gumelnița ce au locuit tell-ul de la Hârşova sunt reprezentate de moluște, crustacee, pești, țestoase și păsări. Culesul moluștelor pescuitul sau vânătoarea au fost activități ce au contribuit la paleoeconomia animalieră a acestor comunități iar cercetarea arheologică de la Hârșova tell în special cea coordonată de Dragomir Nicolae Popovici în colaborare cu echipa franceză a reuşit sa cuantifice, să detalieze și să surprindă modul lor de evoluție de-a lungul locuirii eneolitice.

Studiile detaliate au pus în evidență modele oportuniste dar și strategice de obținere şi utilizare a resurselor ce indică faptul că aceste comunități preistorice aveau o capacitate ridicată de a exploata eficient resursele alimentare

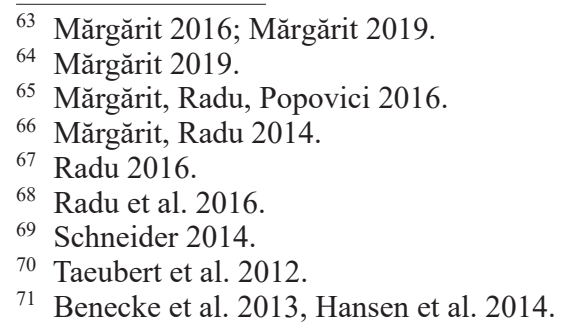


de natură animală pe tot parcursul anului pentru a obține o dietă echilibrată.

Pescuitul este evidențiat prin prezența a cel puțin 21 specii de pești, majoritatea de apă dulce. Importanța alimentară a peștelui crește în perioada Gumelnița odată cu exploatarea intensivă şi a altor resurse din mediului înconjurător precum animalele vânate. Dimensiunile de pescuit scad, dar crește cantitatea și varietatea specifică, parametri care se mențin la sfârșitul perioadei Gumelnița. De asemenea culesul bivalvelor devine intensiv fapt ce a permis surprinderea fenomenului de supracules acesta fiind printre primele manifestări ale modificărilor antropice în ecosistemele naturale demonstrate în preistorie. S-a reușit pe baza ecologiei animalelor dar și a resturilor asociate depozitelor arheologice stabilirea unor repere temporale și sezonalitatea anumitor activități legate de organizarea structurilor arheologice, a spațiului locuit și chiar a evoluției acestor locuiri în raport cu schimbările mediului înconjurător.

Cercetările viitoare privind rolul resurselor acvatice vor fi direcționate mai ales în descifrarea relației sezoniere a diversele surse de hrană de natură animală precum studiile de dată recentă ce au implicat analize complexe ${ }^{72}$. De asemenea realizarea de noi analize multi-proxi, precum și interrelationarea datelor și informațiilor obținute deja de la diverse cercetări pluridisciplinare vor contribui la cunoașterea și detalierea multiplelor aspecte ale relațiilor dintre comunitățile umane și mediu în care au locuit.

\section{BIBLIOGRAFIE}

Balasse et al. 2016

Balasse, M., Evin ,A., Tornero, C., Radu, V., Fiorillo, D., Popovici, D., Andreescu, R., Dobney, K, Cucchi, T., Bălășescu, A., Wild, domestic and feral? Investigating the status of suids in the Romanian Gumelnița $\left(5^{\text {th }}\right.$ mil. cal BC) with biogeochemistry and geometric morphometric,. Journal of Anthropological Archaeology, 42, 2016, 24-36.

Balasse et al. 2017 Balasse, M., Bălăşescu, A., Tornero, C., Fremondeau, D., Hovsepyan, R., Gillis, R., Popovici, D. N., Investigating the scale of herding in Chalcolithic pastoral communities settled by the Danube river in the 5th millennium BC: a case study at Borduşani-Popină and Hârşova-tell (Romania), Quaternary International, 436, Part B, 2017, 29-40.

Bălăşescu, Radu 2004 Bălăşescu, A., Radu, V., Omul şi animalele. Strategii şi resurse la comunităţile Hamangia şi Boian, Biblioteca Muzeului Naţional, Seria Cercetări Pluridisciplinare, IX, Editura Cetatea de Scaun, Târgovişte, 2004.

Bălăşescu, Moise, Radu 2005

Bălăşescu, A., Moise, D., Radu, V., The palaeoeconomy of Gumelniţa communities on the territory of Romania, Cultură şi Civilizaţie la Dunărea de Jos, XXII, 2005, 167-206.

Bălăşescu, Radu, Moise Bălăşescu, A., Radu, V., Moise, D., Omul si mediul animal în mileniile VII- IV la 2005

Bălăşescu, Moise, Radu 2006 Dunărea de Jos, Biblioteca Muzeului Naţional, Seria Cercetări Pluridisciplinare, XI, Editura Cetatea de Scaun, Târgovişte, 2005.

Bălăşescu, A., Moise, D., Radu, V., Une utilisation des bovins pour la traction pendant le Chalcolithique en Roumanie ?, în Petrequin, P., Arbogast, R.-M., Petrequin, A.-M., van Willingen, S., Bailly, M. (eds.), Premiers chariots, premiers araires. La diffusion de la traction animale en Europe pendant les IV et III millénaires avant notre ère, CRA Monographies 29, CNRS éditions: Paris, 2006, 269-273.

Benecke et al. 2013 Benecke, N., Hansen, S., Nowacki, D., Reingruber, A., Ritchie, K., Wunderlich, J., Pietrele in the Lower Danube region: integrating archaeological, faunal and environmental investigations, Documenta Praehistorica, XL, 2013, 145-193.

Bréhard, Bălăşescu 2012 Bréhard, S., Bălăşescu,A., What’s behind the tell phenomenon?Anarchaeozoological approach of Eneolithic sites in Romania, Journal of Archaeological Science, 39, 2012, 3167-3183.

\footnotetext{
72 Brehard et al. 2014; Radu 2016; Balasse et al. 2017.
} 
Bréhard et al. 2014

Casteel 1976

Claassen 1998

Cronica 1983-2017

Desse-Berset, Radu 1996

Desse-Berset, Radu 2006

Evin et al. 2015

Gál, Kessler 2002

Galbenu 1962

Galbenu 1963

Galbenu 1966

Galbenu 1979

Haită 2000

Haită 2001

Haită 2012a

Haită 2012b

Haită, Radu 2003
Bréhard, S., Radu, V., Martin, A., Pauline H., Popovici, P., Bălăşescu, A., Food supply strategies in the Romanian Eneolithic: sheep/goat husbandry and fishing activities from Hârşova tell and Borduşani-Popină ( $5^{\text {th }}$ millennium BC), European Journal of Archaeology, 17 (3), 2014, 407-433.

Casteel, R. W., Fish Remains in Archaeology and Paleoenvironmental Studies, Academic Press, London, New York, 1976.

Claassen, C., Shells. Cambridge University Press: Cambridge, 1998.

Cronica cercetărilor arheologice din România, 1983-2012. Rapoarte preliminare de cercetare arheologică, http://cronica.cimec.ro/CercetariARH.asp, accesat 18.12.2019.

Desse-Berset. N., Radu, V., Stratégies d'échantillonnage et d'exploitation des restes osseux de poissons pour une approche paléoenvironnementale et paléoéconomique: l'exemple d'Hârşova Roumanie, (Néolithique final-Chalcolithique), in Langouet, L. (ed.), Actes du Colloque d'Archéométrie 1995, Périgueux (Dordogne, France), Revue d'Archéométrie, supplément, 1996, 181-186.

Desse-Berset, N., Radu, V., Les premiers pêcheurs d'Hârșova (Dobrogea, Roumanie), Cercetări arheologice, XIII, 2006, 393-407.

Evin, A., Girdland Flink, L., Bălășescu, A., Popovici, D., Andreescu, R., Bailey, D., Mirea, P., Lazăr, C., Boroneanţ, A., Bonsall, C., Strand Vidarsdottir, U., Brehard, S., Tresset, A., Cucchi, T., Larson, G., Dobney, K., Unravelling the complexity of domestication: A case study using morphometrics and ancient DNA analyses of archaeological pigs from Romania, Philosophical Transactions B, 370, 1660, 2015, 20130616-20130616.

Gál, E., Kessler, E., Bird remains from the Eneolithic and Iron Age site BorduşaniPopină and Eneolithic site Hârşova (Southeast Romania), Acta zoologica cracoviensia, 45 (special issue), 2002, 253-262.

Galbenu, D., Așezarea neolitică de la Hârşova, SCIV, 13, 2, 1962, 285-306.

Galbenu, D., Neoliticeskaia masterskaia dlea obrabotk ukraşenîi v Hârşova, Dacia N. S., VII, 1963, 501-509.

Galbenu, D., 1966, Nouvelles données concernant le dèbut de la civilisation de Gumelnița de Dobrogea, Dacia N. S., X, 1966, 321-325.

Galbenu, D., Săpături în tell-ul de la Hârşova, jud. Constanţa, Cercetări Arheologice, III, 1979, 3-8.

Haită, C., Sédimentologie, în Popovici, D., Randoin, B., Rialland Y., Voinea, V., Vlad, F., Bem, C., Bem Carmen, Haită, G., Les recherches archéologiques du tell de Hârşova (dép. de Constantza), 1997-1998, Cercetări Arheologice, XI, 2000, 48-55.

Haită, C., Studiu micromorfologic asupra spaţiilor amenajate din interiorul locuinţelor din siturile neo-eneolitice Hârşova-tell şi Borduşani-Popină, Culture et Civilisation au Bas Danube, Préhistoire du Bas Danube, Muzeul Dunării de Jos, Călăraşi, XVI-XVII, 2001, 48-52.

Haită, C., Micromorphological Analysis of Anthropic Sequences from Tell Settlements in Muntenia and Dobrogea (southern Romania), în Cotiugă, V., Caliniuc, S. (eds.), Interdisciplinarity Research in Archaeology (British Archaeological Reports International Series, 2433, Archaeopress: Oxford, 2012, $37-44$

Haită, C., Observations at microscope on pottery fabric of some ceramic fragments from Gumelniţa tell settlements Hârşova and Borduşani Popină, Studii de Preistorie, 9, 2012, 113-121.

Haită, C., Radu, V., Les zones de rejets ménagères de la culture Gumelniţa: témoins dans l'évolution chrono-stratigraphique des tells. Etude micromorphologique et archéo-ichthyologique sur le tell d'Hârşova (dép. Constanţa), Cercetări Arheologice, XII, 2003, 389-401. 
Haşotti 1989

Haşotti 1997

Haşotti, Popovici 1992

Hansen et al. 2014

Larson et al. 2007

Leng, Lewis 2016

Le Bailly et al. 2006

Mărgărit 2016

Mărgărit 2019

Mărgărit, Popovici 2011

Mărgărit, Popovici 2012a

Mărgărit, Popovici 2012b

Mărgărit, Radu 2014

Mărgărit, Radu, Popovici 2016

Moise 2000

Monah 2000
Haşotti, P., Consideraţii cu privire la cultura Gumelniţa în Dobrogea, Pontica, XXI-XXII, 1989, 13-29.

Haşotti, P., Epoca neolitică în Dobrogea, Bibliotheca Tomitana, Constanţa, 1997.

Haşotti, P., Popovici, D., Cultura Cernavodă I în contextul descoperirilor de la Hârşova, Pontica, XXV, 1992, 15-44.

Hansen, S., Toderas, M., Wunderlich, J., Beutler, K., Benecke, N., Dittus, A., Karaucak, M., Müller, M., Nowacki, D., Pint, A., Price, T. D., Ritchie, K., Steiniger, D., Vachta, T., Pietrele am „Lacul Gorgana“. Bericht über die Ausgrabungenin der neolithischen und kupferzeitlichen Siedlung und die geomorphologischen Untersuchungenin den Sommern 2012-2016, Eurasia Antiqua, 20, 2014, 1-115.

Larson, G., Albarella, U., Dobney, K., Rowley-Conwy, P., Schibler, P., Tresset, A., Vigne, J.-D., Edwards, C., Schlumbaum, A., Dinu, A., Bălăşescu A., Dolman, A, Tagliacozzo G., Manaseryan, N., Miracle P., Van Wijngaarden-Bakker, L., Masseti M., Bradley, D.G., Cooper A., Ancient DNA, pig domestication, and the spread of the Neolithic into Europe, Proceeding of the National Academy of Sciences of the United States of America (PNAS), vol. 104, no. 39, 2007, 15276-15281

Leng, M.J., Lewis, J.P., Oxygen isotopes in Molluscan shell: Applications in environmental archaeology, Environment archaeology, 21 (3), 2016, 295-306.

Le Bailly, M., Bălăşescu, A., Popovici, D., Barbin, V., Paicheler, J.-C., Nouvelle approche taphonomique des coprolithes du Tell d'Hârş̧ova (Roumanie): Contribution de la cathodoluminescence, Compte Rendus Palevol, 5, 2006, 919-925.

Mărgărit, M., Testing the endurance of prehistoric adornments: Raw materials from the aquatic environment, Journal of Archaeological Science, 70, 2016, 66-81.

Mărgărit, M., Personal adornments in the prehistory of the Northern Danube area, Editura Cetatea de Scaun, Târgoviște, 2019.

Mărgărit, M., Popovici, D. N. Production and function of barbed points from the Gumelniţa tell of Hârşova (Constanţa County), Analele Banatului, ArheologieIstorie, S. N., XIX, 2011, 33-49

Mărgărit, M., Popovici, D. N., From block to finished object. Function of the personal ornaments in the eneolithic settlement from Hârşova-tell (judeţul Constanța, România), Acta Archaeologica Carpathica, XLVII, 2012, 91-114.

Mărgărit, M., Popovici, D. N., Another facet of the man - Red deer relationship in prehistory: Antler exploitation at the Eneolithic settlement at Hârşova-tell (Constanța County, Romania), Documenta Praehistorica, 39, 2012, 325-344.

Mărgărit, M., Radu, V., The use of autochthonous aquatic resources in the technologies of Gumelnița communities/ Utilizarea resurselor acvatice autohtone în tehnologiile comunităților gumelnița, în Mărgărit, M., Le Dosseur, G., Averbouh, A. (eds.), An overview of the exploitation of hard ani mal materials during the Neolithic and Chalcolithic/ $O$ privire asupra exploatării materiilor dure animale de-a lungul neoliticului și calcoliticului, Proceedings of the GDRE PREHISTOS Work-Session in Târgovişte, România, November 2013, Editura Cetatea de Scaun, Târgoviște, 2014, 221-239

Mărgărit, M., Radu, V., Popovici, D. N. From operculum to bead. Production of pearls from opercular bones of Cyprinus carpio in the Romanian Eneolithic, Environment archaeology, 21 (4), 2016, 351-360.

Moise, D., Etude du matériel ostéologique appartenant aux mammifères découvert dans le Complexe 521 (la zone ménagère) sur le tell néo-énéolithique de Hârşova (dép. de Constantza), Cercetări Arheologice, XI (1), 2000, 84-111.

Monah, F., Rapport préliminaire sur les macrorestes végétaux du complexe ménager 521 - le tell énéolithique Hârşova (dép. Constanţa). Campagne 1998, Cercetări Arheologice XI (1), 2000, 66-74. 
Ollivier et al. 2016

Parnic 2007-2008

Popovici 2010

Popovici, Haşotti 1992

Popovici, Randoin, Rialland 2001

Popovici et al. 1992

Popovici et al. 2000

Popovici et al. 2001

Popovici et al. 2002

Popovici et al. 2012a

Popovici et al. 2012b

Popovici et al. 2014

Popovici et al. 2016

Popovici et al. 2018

Prendergast, Stevens 2013

Radu 1997

Radu 2000
Ollivier, M., Tresset, A., Bastian, F., Lagoutte, L., Axelsson, E., Arendt, M.-L., Bălășescu, A., Marshour, M., Pionnier-Capitan, M., Sablin, M. V., Salanova, L., Vigne, J.-D., Hitte, C., Hänni, C., Amy2B copy number variation reveals starch diet adaptation in European ancient dog, Royal Society Open Science, 3, (11), 160449, 9 p, 2016.

Parnic, A., Noi date privind circulația pe apă în preistorie, Cercetări Arheologice, XIV-XV, 2007-2008, 45-53.

Popovici, D., Copper Age Traditions North of the Danube River, în Anthony, D. W., Chi, J. Y. (eds.), The Lost World of Old Europe. The Danube Valley, 5000-3500 $B C$, Princeton University Press, New York University, 2010, 90-111.

Popovici, D., Haşotti, P., Considerations about the Synchronism of the Cernavoda I Culture, Pontica, XXI-XXII, (1988-1989), 1992, 291-299.

Popovici, D., Randoin, B., Rialland, Y., Le tell néolithique et chalcolithique d'Hârşova (Roumanie), în Guilaine, J., (ed.), Communautés villageoises du Proche-Orient à l'Atlantique (8000-2000 avant notre ère), Séminaire du Collège de France, Edition Errance, Paris, 2001, 119-152.

Popovici, D., Haşotti, P., Galbenu, D., Nicolae, C., Cercetările arheologice din tell-ul de la Hârşova, jud. Constanţa, 1988, Cercetări Arheologice, IX, 1992, 8-11.

Popovici, D., Randoin, B., Rialland, Y., Voinea, V., Vlad, F., Bem, C., Bem, C., Haită, G., Les recherches archéologiques du tell de Hârşova (dép. de Constanţa) 1997-1998, Cercetări Arheologice, XI (1), 2000, 13-123.

Popovici, D., Randoin, B., Voinea, V., Vlad, F., Parnic, V., Bălăşescu, A., Haită, C., Moise, D., Radu, V., Hârşova, jud. Constanţa. Punct: Hârşova Tell, http://www.cimec. ro/Arheologie/CronicaCA2001/rapoarte/rapoarte_maine.htm, vizitat la 18.12.2019.

Popovici, D., Bălășescu, A., Haită, C., Radu, V., Tomescu, A.M.F., Tomescu, I., Cercetarea arheologică pluridisciplinară. Concepte, metode și tehnici, Biblioteca Muzeului Naţional, Seria Cercetări Pluridisciplinare, III, Editura Cetatea de Scaun, Târgoviște, 2002.

Popovici, D., Randoin B., Haşotti P., Rialland Y., Voinea V., Ilie A., Vlad F., Parnic V., Bălăşescu A., Haită, C. Radu V., Collaboration franco-roumaine sur le site archéologique du tell énéolithique d'Hârşova (dep. Constanţa), în Recherches croisées en Dobrogea, Bucharest, 17-18 mai 2012, Supplément de geoEcoMarina, 18, 2012, 41 .

Popovici, D.N., Haită, C., Radu, V., Bălăşescu, A., Randoin, B., Ilie, A., Hârşova, jud. Constanța. Punct: Tell, CCA. Campania 2011, 2012, 63-68 şi Anexa 4, 305-307.

Popovici, D.N., Randoin, B., Cernău, I., Cernea, C., Ilie, A., Haită, C., Bălășescu, A., Radu, V., Mărgărit, M., Nițu, L, R., Hovsepyan, Programul de colaborare romano-francez de la Hârşova-tell, jud. Constanța. Campania 2013, Cercetări Arheologice, XXI, 2014, 25-54.

Popovici, D.N., Randoin, B., Ilie, A., Haită, C., Bălășescu, A., Radu, V., Mărgărit, M., Nițu, L, Programul de colaborare romano-francez de la Hîrșova-tell, jud. Constanța. Campania 2016, Cercetări Arheologice, XXIII, 2016, 17-47.

Popovici, D.N., Randoin, B., Ilie, A., Haită, C., Radu, V., Mărgărit, M., Niţă, L., Hîrşova, jud. Constanța, Hîrşova tell, CCA, Campania 2017, 2018, 46-47 și 253.

Prendergast, A. L., Stevens, R. E., Molluscs (Isotopes): analyses in environmental archaeology, în Smith, C. (ed.), Encyclopaedia of Global Archaeology, Springer, New York, 2013, 5010-5019.

Radu V., Archaeological researches at Borduşani-Popina (Ialomiţa county). Preliminary report 1993-1994. Eneolithic occupation. Archaeozoology. Pisces, Cercetări Arheologice, X, 1997, 96-105.

Radu V., Sur la durée d'utilisation d'une zone de rejets ménagers appartenant à la culture Gumelnita A2 du tell d'Hârșova. Etude archéologique préliminaire, Cercetări Arheologice, XI (1), 2000, 75-83. 
Radu 2001

Radu 2003a

Radu 2003b

Radu 2007-2008

Radu 2011a

Radu 2011b

Radu 2016

Radu et al. 2016

Randoin, Popovici, Rialland 2000

Ritchie 2017

Sárkány-Kiss, Boloş 1996

Schneider 2014

Schöll-Barna et al. 2012

Ştefan 2010
Radu V., Aşezarea eneolitică de pe insula „La Ostrov”, Lacul Taşaul (Năvodari, jud. Constanţa). Raport preliminar - Campaniile 1999-2000. Studiul materialului arheoihtiologic. Pontica, XXXIII-XXXIV, 2001, 65-170.

Radu, V., Several data about fish and fishing importance in the palaeoconomy of the gumelniţa A2 community from Borduşani-Popină, in Popovici, D., Haită, C, Bălăşescu, A., Radu, V., Vlad, F., Tomescu, I., Archaeological pluridisciplinary researches at Borduşani-Popină, Seria cercetări pluridisciplinare, VI, Editura Cetatea de Scaun, Târgovişte, 2003, 159-171.

Radu, V., L'étude préliminaire du matériel archéo-ichtyologique provenant des niveaux Gumelniţa A2 de l'établissement Luncaviţa-Cetăţuie (dép. Tulcea), Peuce SN, I, p. 2003, 469-476.

Radu, V., 2007-2008, Quelques engins de pêche employés pendant la période néoénéolithique sur le territoire de la Roumanie, Cercetări Arheologice, XIV-XV, 2007-2008, 413-421.

Radu, V., Le Néolithique de la Roumanie Méridionale: Exploitation des ressources aquatiques dans les cultures Boian et Gumelniţa, Editions Universitaires Européennes: Sarrebruck, 2011.

Radu, V., Exploitation des ressources animales aquatiques aux périodes néo- et énéolithique de la vallée de Teleorman, în Mills, S., Mirea, P. (eds.), The Lower Danube in Prehistory: Landscape changes and human-environment interactions, Proceedings of the International Conference Alexandria, 3-5 November 2010, Editura Renaissance, București, 2011, 161-166.

Radu, V., The Lower Danube mollusc assemblages: zooarchaeological and palaeoenvironment data from Chalcolithic settlements $\left(5^{\text {th }}\right.$ millennium $\left.\mathrm{BC}\right)$, prezentare susținută la conferința internațională The archaeology of wetlands, the landscape, the man and his environment: Danube Valley in Prehistory, 15-16 iunie 2016, Muzeul Național de Istorie, București.

Radu, V., Popovici, D.N., Cernea, C., Cernău, I., Bălăşescu, A., Harvesting molluscs in the Eneolithic: a study of freshwater bivalve accumulations from the tell settlements of Bordușani-Popină and Hârșova (Romania, $5^{\text {th }}$ millennium BC), Environment archaeology, 21 (4), 2016, 334-350.

Randoin, B., Popovici, D., Rialland, Y., Metoda de săpătură și înregistrarea datelor stratigrafice într-un sit pluristratificat: tell-ul Neo-Eneolitic de la Hârşova, Cercetări Arheologice, XI (1), 2000, 199-234.

Ritchie, K., Mixing copper and water: the aquatic focus of Chalcolithic Romania, în Mărgărit, M., Boroneanț A. (eds.), From hunter-gatherers to farmers. Human adaptations at the end of the Pleistocene and the first part of the Holocene, Papers in Honour of Clive Bonsall, Editura Cetatea de Scaun Târgoviște, 2017, 329-338.

Sárkány-Kiss, A., Boloş, F., Malacological aspects of the archaeological excavations in the Neo-Eneolithic settlement at Hârşova, oral presentation sustained at International Conference ,,Vivre au bord du Danube il y a 6500 ans”, Bucureşti, 13-15 November, 1996.

Schneider, L.D., Ecology of the threatened thick-shelled river mussel Unio crassus (Philipsson 1788) with focus on mussel-host interactions, Introductory paper, 11, 2014.

Schöll-Barna, G., Demény, A., Serlegi, G., Fábián, S., Sümegi, P., Fórizs, I., Bajnóczi, B., Climatic variability in the Late Copper Age: stable isotope fluctuation of prehistoric Unio pictorum (Unionidae) shells from Lake Balaton (Hungary), Journal of Paleolimnology, 47 (1), 2012, 87-100.

Ştefan, C.E., Settlement types and enclosures in the Gumelniţa Culture, Editura Cetatea de Scaun, Târgovişte, 2010. 
Taeubert et al. 2012

Tomescu 2000a

Tomescu 2000b

Tomescu 2004

Tomescu, Radu, Moise 2003
Taeubert, J.E., Posada Martinez, A.M, Gum, B., Geist, J., The relationship between endangered thick-shelled river mussel (Unio crassus) and its host fishes, Biological Conservation, 155, 2012, 94-103.

Tomescu, M., Holocenul - Date cronologice şi climatice, Cercetări Arheologice, XI (1), 2000, 235-270.

Tomescu, M., Les coprolithes de l'accumulation de rejets domestique C521 (Hârșova tell, dép. Constantza). Problematique generale et implications de leur dostribution, Cercetări Arheologice XI (1), 2000, 56-65.

Tomescu, I., Studiul resturilor lemnoase în arheologie: paleoecologie şi paleoetnografie, Biblioteca Muzeului Național, Seria Cercetări Pluridisciplinare, VII, Editura Cetatea de Scaun, Târgovişte, 2004.

Tomescu, A.M.F., Radu, V., Moise, D., High Resolution Stratigraphic Distribution of Coprolites within Eneolithic Middens, a Case Study: Hârșova-Tell (Constanța County, Southeast Romania), Environmental Archaeology, 8, 2003, 97-109.

\section{LIST OF ILLUSTRATIONS}

Figure 1. Faunal remains analyzed in this study from Hârşova tell (Boian and Gumelnița levels).

Figure 2. Total length $(\mathrm{Lt})$ calculated on the dimensions of the first ray of the wels catfish pectoral fin (Silurus glanis). The Boian sample comes from the waste areas identified in the SC/pP, campaigns 2016-2017 and the Gumelniţa one from SB, the waste area C521.

Table 1. Comprehensive list of mollusc taxa identified in the Boian and Gumelnița cultural levels from Hârşova tell. Table 2. Comprehensive list of fish taxa identified in the Boian and Gumelnița cultural levels from Hârșova tell.

VALENTIN RADU, Muzeul Național de Istorie a României, valipeste@yahoo.com 
Tabelul 1. Lista detaliată a moluștelor identificate în nivelurile culturale Boian și Gumelnița de la Hârșova tell.

\begin{tabular}{|c|c|c|c|c|c|c|c|c|}
\hline \multirow{3}{*}{ Taxoni } & \multicolumn{4}{|c|}{ Gumelnița } & \multicolumn{4}{|c|}{ Boian } \\
\hline & \multicolumn{3}{|c|}{ campanii arheologice } & \multirow[t]{2}{*}{ Total } & \multicolumn{3}{|c|}{ campanii arheologice } & \multirow[t]{2}{*}{ Total } \\
\hline & 1994-2000 & 2006 & 2011 & & 1994 & 2016 & 2017 & \\
\hline \multicolumn{9}{|l|}{$\begin{array}{l}\text { GASTROPODA } \\
\text { acvatice }\end{array}$} \\
\hline Theodoxus danubialis & 132 & & & 132 & 4 & & & 4 \\
\hline Theodoxus fluviatilis & 21 & & & 21 & & & & \\
\hline Theodoxus sp. & & & 5 & 5 & & & 3 & 3 \\
\hline Viviparus acerosus & 1415 & & & 1415 & & & & \\
\hline Viviparus contectus & 4 & & & 4 & & & & \\
\hline Viviparus sp. & & 11 & 2 & 13 & & 3 & 7 & 10 \\
\hline Valvata piscinalis & 20 & & & 20 & & & & \\
\hline Valvata pulchella & 18 & & & 18 & & & & \\
\hline Lithoglyphus naticoides & 173 & & 14 & 187 & & & 5 & 5 \\
\hline Bithynia tentaculata & 1 & & & 1 & & & & \\
\hline Bithynia leachi & 8 & & & 8 & & & & \\
\hline Esperiana esperi & 119 & & & 119 & 2 & & & 2 \\
\hline Esperiana acicularis & 15 & & 3 & 18 & & & & \\
\hline Planorbis planorbis & 2 & & & 2 & & & & \\
\hline $\begin{array}{l}\text { Planorbarius corneus } \\
\text { terestre }\end{array}$ & 5 & & & 5 & & & & \\
\hline Condrula tridens & 2 & & & 2 & & & & \\
\hline Helicella obvia & 19 & & & 19 & & & & \\
\hline Campilea faustina & 3 & & & 3 & & & & \\
\hline Cepaea vindobonensis & 7 & & & 7 & & & & \\
\hline Total Gastropoda & 1964 & 11 & 24 & 1999 & 6 & 3 & 15 & 24 \\
\hline \multicolumn{9}{|l|}{$\begin{array}{l}\text { BIVALVIA } \\
\text { dulcicole }\end{array}$} \\
\hline Unio tumidus & 14989 & 6 & 64 & 15059 & 23 & 168 & 285 & 476 \\
\hline Unio pictorum & 17551 & 4 & 29 & 17584 & 22 & 145 & 39 & 206 \\
\hline Unio crassus & 335 & 3 & 44 & 382 & 11 & 69 & 349 & 429 \\
\hline Unio sp. & 15252 & 72 & 302 & 15626 & 144 & 414 & 272 & 830 \\
\hline Anodonta cygnaea & 1501 & 74 & 87 & 1662 & 16 & 76 & 50 & 142 \\
\hline Pseudanodonta complanata & $\mathrm{x}$ & & & & & & & \\
\hline Sphaerium solidum & 3 & & 2 & 5 & & & & \\
\hline $\begin{array}{l}\text { Dreissena polymorpha } \\
\text { marine } \\
\text { Cerastoderma (Cardium) } \\
\text { edule }\end{array}$ & 3142 & 29 & 21 & 3192 & 9 & 2 & 2 & 13 \\
\hline Total Bivalvia & 52801 & 188 & 550 & 53539 & 225 & 874 & 997 & 2096 \\
\hline $\begin{array}{l}\text { SCAPHOPODA } \\
\text { Dentalium sp. }\end{array}$ & 17 & & & 17 & & & & \\
\hline Total moluște & 54782 & 199 & 574 & 55555 & 231 & 877 & 1012 & 2120 \\
\hline
\end{tabular}


Tabelul 2. Lista detaliată a peștilor identificați în nivelurile culturale Boian și Gumelnița de la Hârșova tell.

\begin{tabular}{|c|c|c|c|c|c|c|c|c|}
\hline \multirow{3}{*}{ Taxoni } & \multicolumn{4}{|c|}{ Gumelnița } & \multicolumn{4}{|c|}{ Boian } \\
\hline & \multicolumn{3}{|c|}{ campanii arheologice } & \multirow[t]{2}{*}{ Total } & \multicolumn{3}{|c|}{ campanii arheologice } & \multirow[t]{2}{*}{ Total } \\
\hline & $1994-2000$ & 2006 & 2011 & & 1994 & 2016 & 2017 & \\
\hline Sturioni & 866 & 441 & 7 & 1314 & 66 & 38 & 187 & 291 \\
\hline Acipenser ruthenus & 3 & 10 & & 13 & & & & \\
\hline Acipenser stellatus & 15 & 15 & & 30 & & & & \\
\hline Huso huso & & & & & & & 17 & 17 \\
\hline Alosa pontica & 2 & & & 2 & & & & \\
\hline Esox lucius & 9001 & 196 & 47 & 9244 & 40 & 11 & 19 & 70 \\
\hline Alburnus alburnus & 14 & & & 14 & & & & \\
\hline Abramis brama & 1868 & 138 & 16 & 2022 & 40 & & 4 & 44 \\
\hline Aspius aspius & 102 & 9 & 2 & 113 & 1 & & 1 & 2 \\
\hline Blicca bjoerkna & 491 & 14 & & 505 & 4 & & 6 & 10 \\
\hline Carassius carassius & 2 & & & 2 & & & & \\
\hline Cyprinus carpio & 6448 & 238 & 680 & 7366 & 506 & 58 & 184 & 748 \\
\hline Cyprinidae IND & 77843 & 3594 & 659 & 82096 & 1002 & 16 & 237 & 1255 \\
\hline Leuciscus idus & 78 & & & 78 & & & & \\
\hline Pelecus cultratus & 166 & 35 & & 201 & 1 & & & 1 \\
\hline Rutilus rutilus & 1680 & 46 & 4 & 1730 & 14 & & 10 & 24 \\
\hline $\begin{array}{l}\text { Scardinius } \\
\text { erythrophthalmus }\end{array}$ & 421 & 40 & & 461 & & & 5 & 5 \\
\hline Tinca tinca & 47 & & & 47 & 3 & & & 3 \\
\hline Silurus glanis & 6888 & 389 & 82 & 7359 & 120 & 86 & 456 & 662 \\
\hline Acerina cernua & 1447 & 2 & & 1449 & & & & \\
\hline Perca fluviatilis & 1350 & 26 & 3 & 1379 & 14 & & 9 & 23 \\
\hline Sander lucioperca & 9305 & 188 & 46 & 9539 & 66 & 7 & 30 & 103 \\
\hline Percidae IND & 467 & 15 & & 482 & & & & \\
\hline Anquilla anquilla & & 1 & & 1 & & & & \\
\hline Pisces IND & 141974 & 14680 & 3360 & 160014 & 3218 & 52 & 585 & 3855 \\
\hline Total pești & 260478 & 20077 & 4906 & 285461 & 5095 & 268 & 1750 & 7113 \\
\hline
\end{tabular}

